\title{
Paradigm Shift in Dental Education due to COVID-19
}

ISSN: 2637-7764

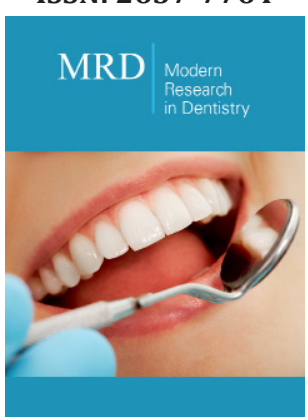

*Corresponding author: Azrul Hafiz, Faculty of Dentistry, Islamic Sciences University of Malaysia, Malaysia

Submission: 诫 April 16, 2021

Published: 漹April 21, 2021

Volume 6 - Issue 2

How to cite this article: Azrul Hafiz Paradigm Shift in Dental Education due to COVID-19. Mod Res Dent. 6(2). MRD. 000634.2021

DOI:_10.31031/MRD.2021.06.000634

Copyright@ Azrul Hafiz, This article is distributed under the terms of the Creative Commons Attribution 4.0 International License, which permits unrestricted use and redistribution provided that the original author and source are credited.
Azrul Hafiz*

Faculty of Dentistry, Islamic Sciences University of Malaysia, Malaysia

\section{Opinion}

The COVID-19 pandemic has taken the world by surprise. New norms were being explored to curb the spread of the deathly virus. A typical pneumonia in Wuhan were unexpectedly burst into new deadly viral disease [1]. The virus has not only significantly affected the people health but also caused devastating effect on economy, social and education sector. In the initial period of the COVID-19, government around the world have introduce a total lockdown procedure for several months. People with or without COVID-19 symptom were advice to stay at home and restricted their movement. For those who have been contacted by the virus or suspected being infected were send for screening at health facilities. Individual with positive result from the test were being send to a quarantine facility. Physical distancing, hand sanitizing and compulsory face mask in public places were made mandatory in this period. This were done to reduce the infection curved and lower the number of affected people.

Higher learning institution were also force to adherence in this new procedure. Face to face classes being cancel and online teaching were being introduce as substitute to normal classroom [2]. The COVID-19 pandemic has force higher learning institute to rethink and redesign their mode of education, research and governance into online methods. Fortunately, online learning is not a new concept, as early as 1980s people were discussing about distance learning using computers and their challengers [3]. Since then, many paraphrases have been used to describe distance learning such as tele-education, virtual classes, e-learning and online class. Previously, these methods were considered as a small part of formal education to increase the use of technology in education. Nowadays, it seems online education could replace the formal face to face education. However, the effectiveness of online education is still in doubted as pointed out by some researchers [4]. They found that the successful of virtual learning is depends on the student attitude and personality rather than the technology itself. With all the devices provided, without self-control, discipline and the correct mindset, the education process is doomed to fail. During the lockdown period most of the online course were carried out with the teacher giving lectures and student were expected to watch and learned [5]. Both teacher and student were compelled to adopt the digital education as a part of their teaching-learning process.

Traditionally, dental education emphasizes on hands-on clinical learning and many practical sessions. At the peak of COVID-19, dental faculties were forced to substitute several of this session into online teaching. A swift change to online mode from practical session were harshly done during COVID-19 lockdown. Consequently, a non-face-to-face communication and poor adjustment to latest technology were found to be the major problem of online education [6]. Apart from that, poor internet connection and disturbance from background noise were reported to hindering online education process [7]. Some students were also encounter problem such as the unavailability of electronic devices, expensive subscription to internet provider and poor concentration during online classes. Fatigue during listening to online lecture were also being reported as difficulties with the virtual learning [8]. Gazing on laptop/desktop/handphone screen for a long period could constrain the eye and reduce mental focus. To overcome the problems, government were advised to ensure the accessibility of electronic devices, high quality online educational involvement and promote technology for student to achieve an uninterrupted learning experience [9]. In a positive tone, many students expressed their enjoyment during online education. Student were more flexible as they could 
pre-recorded lectures, more time to do other stuff and not have to travel from one classroom to another [10].

In conclusion, dental education in the time of pandemic needs a paradigm shift from psychical classrooms to virtual and online platforms. Social distancing, personal protective equipment and enhance safety procedure will become the new norms. A new method of teaching is needed to improve the learning process in this new era. Dental lecturers need to be train in the use of new online skill and software to deliver their lecturer in interesting and modern way. This is to adapt the trend of the new z-generation students which are propounded to the latest technology. The COVID-19 pandemic will be here to stay for many years and the adaptability of dental school is a must.

\section{References}

1. Sara P, Tongtong X, Ernesto C (2020) COVID-19: an announced pandemic Cell Death \& Diseases 11: 799-812.

2. Marek T (2020) Towards a post-Covid-19 "New Normality?": Physical and social distancing, the move to online and higher education. Policy Future in Education 18(5): 556-559.

3. Max B (1980) Using computers in distance education: The first ten years of the British Open University. Computers \& Education 4(4): 293-301.
4. Huang R, Tlili A, Chang TW, Zhang X, Nascimbeni F, et al. (2020) Disrupted classes, undisrupted learning during COVID-19 outbreak in China: Application of open educational practices and resources. Smart Learning Environments 7(1): 1-15.

5. Hong JC, Lee YF, Ye JH (2021) Procrastination predicts online selfregulated learning and online learning ineffectiveness during the coronavirus lockdown. Pers Individ Dif 174: 110673.

6. Amir MK, Somdatta P, Neelam V, Mohit M, Renu C (2021) Rapid transition to online practical classes in preclinical subjects during COVID-19: Experience from a medical college in North India. Medical Journal Armed Forces India 77(1): S161-S167.

7. Subhangi G, Aashima D, Swarnim S, Devendra M (2021) Medical education during COVID-19 associated lockdown: Faculty and students' perspective. Medical J Armed Forces India 77(1): 79-84.

8. Faiz T, Aussama KN, Mohamed KK, Lisa MK, Naseer KJ (2021) Students and faculty perception of distance medical education outcomes in resource-constrained system during COVID-19 pandemic. A crosssectional study. Ann Med Surg 62: 377-382.

9. Lokanath M, Tushar G, Abha S (2020) Online teaching-learning in higher education during lockdown period of COVID-19 pandemic. International Journal of Educational Research Open 1: 100012.

10. Chih HL, Hugo YHL (2021) The impact of COVID-19 on medical education: Experiences from one medical university in Taiwan. J Formos Med Assoc. 